\title{
PLANTS
}

\section{THE SALTBUSHES (Atriplex) OF THE PRAIRIE PROVINCES}

DIANA BIZECKI ROBSON, The Manitoba Museum, 190 Rupert Avenue, Winnipeg, Manitoba R3B 0N2, E-mail: <drobson@manitobamuseum.ca>

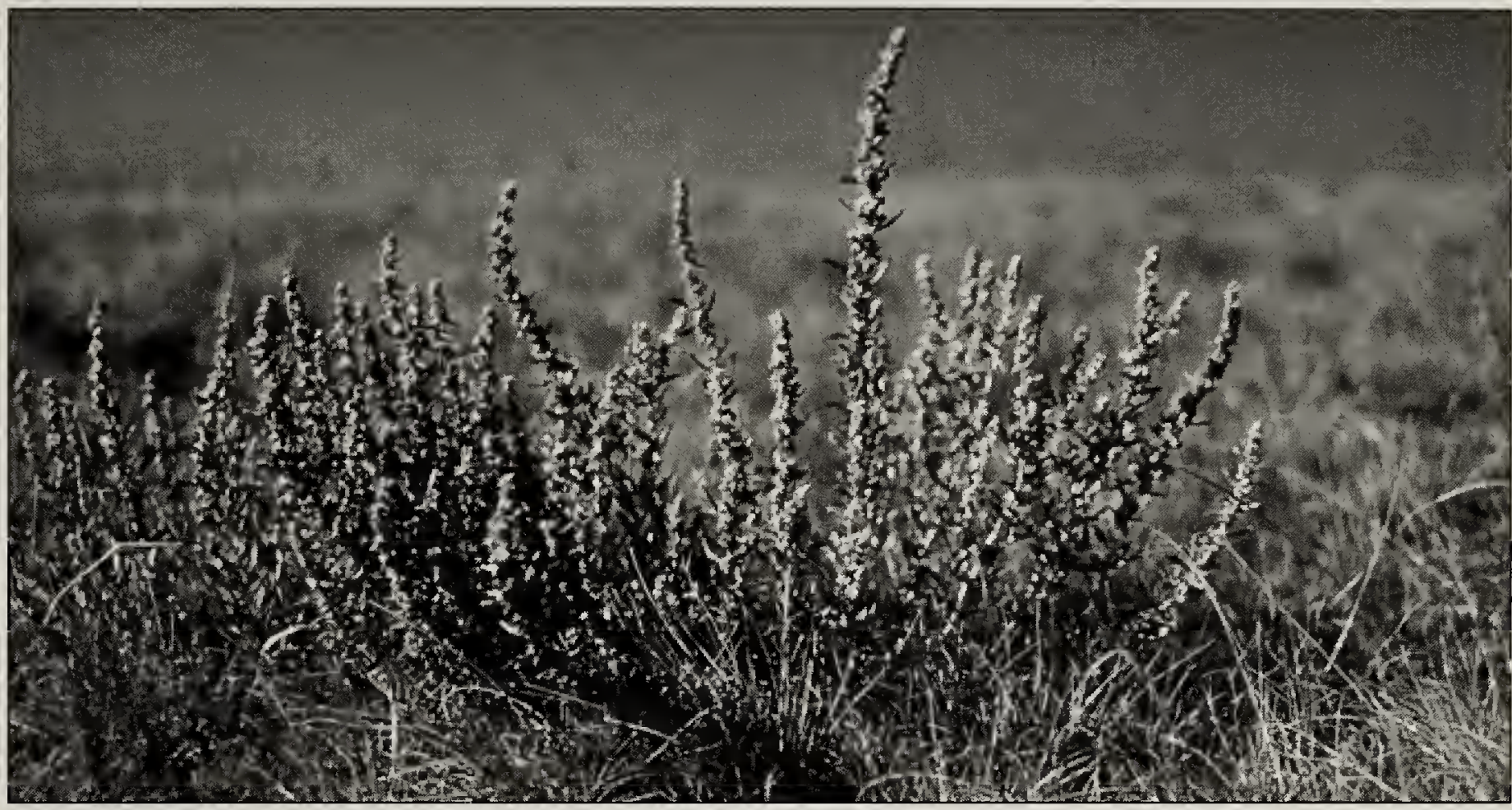

Nuttall's Saltbush (Atiplex gardneri var. gardneri, A. nuttallii)

Jim Romo

\section{Introduction}

The saltbushes (Atriplex) comprise a genus of plants with several uncommon morphological and physiological characters. The common name "saltbush" refers to the fact that most of the species in this genus are tolerant of saline soils. This is a trait that saltbush species share with several other genera in the goosefoot family (Chenopodiaceae). The saltbushes are a difficult group to identify because of their small flowers and highly variable leaf sizes and shapes. In this article I will: (1) discuss the taxonomy, habitat, distribution, status and economic impact of the saltbush or orache (Atriplex) genus, (2) describe the characteristics of Atriplex species, and (3) present a taxonomic treatment of the genus consisting of a dichotomous key and descriptions of those species found in the Canadian prairies. All the species described in this article occur in the midwestern United States except for Glabrous Orache (A. glabriuscula).

In North America, the saltbush genus includes 62 species occurring mainly in the arid west. ${ }^{19}$ In the prairie provinces of Canada, there are 14 species in total, six of which were introduced from Eurasia. The genus recently has been reviewed taxonomically by the Flora of North America committee. ${ }^{19}$ This review resulted in taxonomic changes to several common species. The scientific name of Nuttall's Saltbush ( $A$. nuttallii) is now considered invalid; the valid scientific name is $A$. gardneri. ${ }^{19}$ Two varieties of $A$. gardneri are recognized in western Canada: var. 


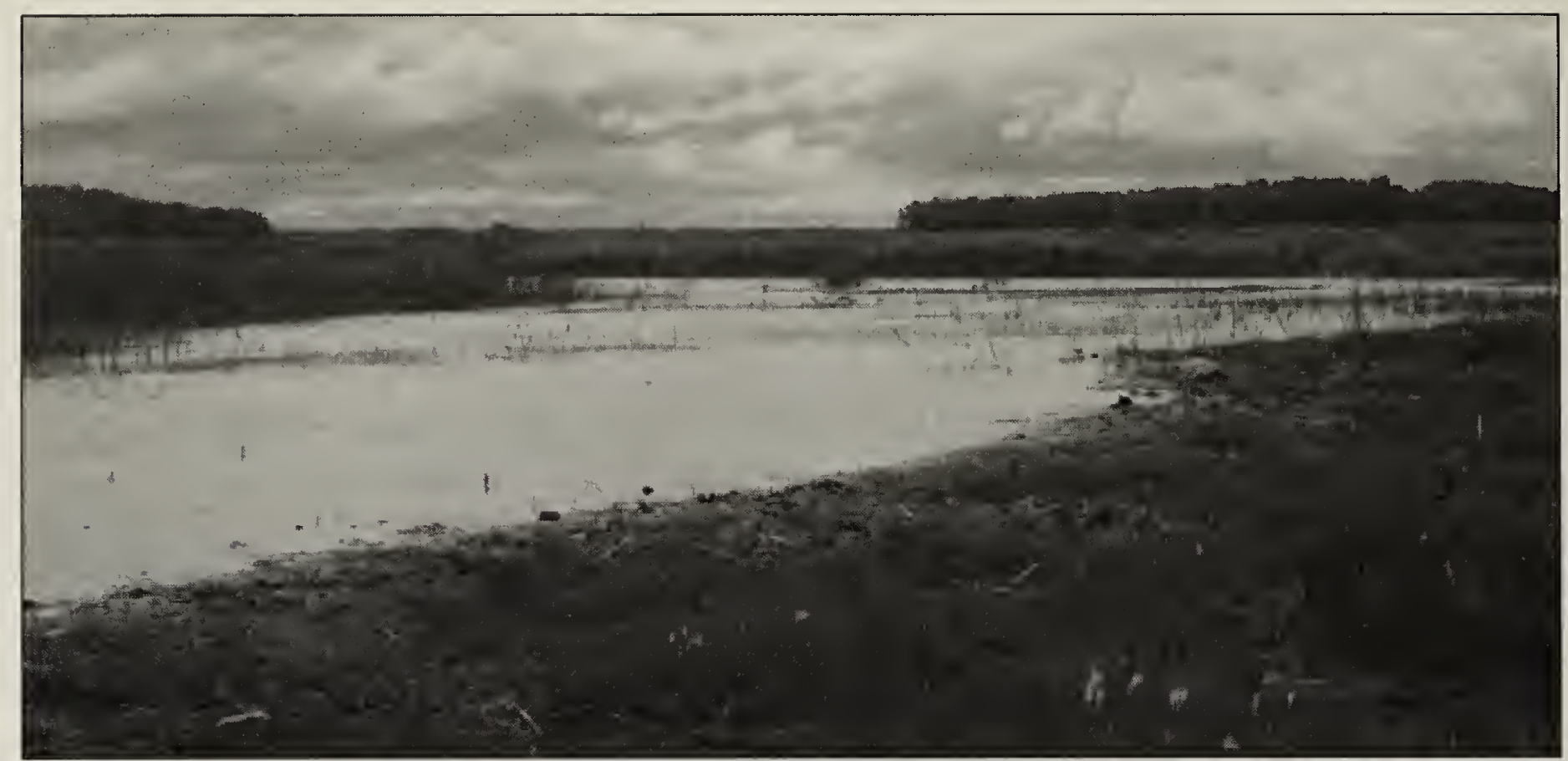

Figure 1. Saline marsh near West Shoal Lake, Manitoba.

D.B. Robson

gardneri and var. aptera, the former commonly called Nuttall's or Gardner's Saltbush, and the latter Nelson's Saltbush. Hastate Orache (A. prostrata) was previously considered to be a variety of Spreading Orache (A. patula), namely $A$. patula var. hastata. Rillscale (Endolepis suckleyi) is now included in the saltbush genus under the name Suckley's Orache (Atriplex suckleyi).

Three species of exotic saltbushes have arrived in Canada in the last several decades: Two-scale Saltbush (A. heterosperma), Oblong-leaf Orache (A. oblongifolia) and Tumbling Orache (A. rosea) to join the three exotics that have been here for much longer.

In a checklist of Saskatchewan's vascular plants, Harms included an additional species of introduced Eurasian saltbush, namely Russian Orache (A. aucheri Moq.). ${ }^{7}$ This inclusion is based on two specimens collected by the late George Ledingham in disturbed habitats in southern Saskatchewan in 1997. They may have arrived in Canada as part of an international shipment of goods, as the specimens were found on CPR tracks and near a landfill. Russian Orache was not included in Flora of
North America, nor is it listed on the Integrated Taxonomic Information System (ITIS) or the United States Department of Agriculture (USDA) websites. Therefore, I have chosen to exclude this species because it does not appear to have become truly naturalized in North America; in fact it may have simply died out. However, it is worth scrutinizing specimens of Garden Orache, which looks very similar to Russian Orache. The latter has bracteoles that are more oblong and $10 \mathrm{~mm}$ or less in diameter, and leaves that are more triangular in shape and slightly smaller $(2-8 \mathrm{~cm})$.

Identification of saltbush species can be difficult as the bracteoles (i.e. highly modified leaves at the base of a flower) are generally needed but are not prominent when the plant is very young. Examination of the bracteoles may require a hand lens, as they often are quite small.

\section{Habitat and Distribution}

Saltbush species occur mainly in saline, alkaline and disturbed habitats (Figure 1). Saline and alkaline habitats have high concentrations of sodium, calcium, magnesium, carbonates, bicarbonates or sulphates. ${ }^{10}$ These 
conditions are toxic to many plants but halophytes and alkaline-tolerant plants have a number of adaptations that make survival in these habitats possible. Saltbush plants accumulate salt in their cells so that saline water can continue to flow into the roots. ${ }^{10}$ However, as salts can be harmful to plant cells, some method of dealing with the salts is needed. Many saltbush species store salts in special hairs, called salt glands or bladders, which are shed periodically to rid the plant of excess salt. ${ }^{3}$ The presence of these glands gives the plants their "scurfy" appearance. The succulence of some species (e.g. Suckley's Saltbush) also contributes to salt tolerance because the stored water dilutes salts, making them less harmful. ${ }^{3,} 10$

Saltbush species are most commonly found in the Prairie ecozone and less commonly in the Boreal Plain ecozone. ${ }^{1}$ All native saltbush species exhibit at least some tolerance to saline or alkaline conditions and are typically restricted to these habitats within the two ecozones. The exception is Glabrous Orache, which is found only in northern Manitoba, near Churchill. ${ }^{8}$ This species has been reported as occurring in northeastern Alberta but the specimen was immature and difficult to positively confirm. Introduced species are typically found along roadsides, disturbed saline areas, and in cultivated fields. ${ }^{4}{ }^{16}$ Garden Orache ( $A$. hortensis) is the most common introduced saltbush species found in the Prairie and Boreal Plain ecozones. ${ }^{4,16}$

\section{Status of the Saltbushes in Canada}

Of the 14 native species found in the Canadian prairies, five are rare either nationally or only provincially. Two saltbush species considered nationally rare are Four-wing Saltbush (A. canescens) and Powell's Saltbush (A. powellii). ${ }^{2}$ Both of these species occur on saline clay flats in southern Alberta and southwestern Saskatchewan. 2, 9, 12 Wedgescale ( $A$. truncata) is considered provincially rare in Alberta and Saskatchewan, and also occurs on saline clay flats. ${ }^{9,12}$ Glabrous Orache ( $A$. glabriuscula) is rare in Manitoba, being found only in salt marshes along Hudson Bay. ${ }^{21}$ Silvery Saltbush ( $A$. argentea) is considered rare in Manitoba but only uncommon in Alberta and Saskatchewan. ${ }^{21}$ In addition to growing in relatively uncommon habitats, the apparent rarity of these species may be influenced by their annual habit and the fact that the seeds may not germinate every year. ${ }^{15}$

Six species of saltbush have been introduced from Eurasia. One of these species, Garden Orache, is a common agricultural weed, which is eaten as a potherb in many countries, including China. ${ }^{18}$ Garden Orache is the alternate host for a number of viral crop diseases. ${ }^{16}$ Spreading Saltbush and Two-scale Saltbush are fairly common weeds in disturbed, saline areas such as ditches..$^{16}$ The remaining introduced species, Oblong-leaf Orache, Hastate Orache, and Tumbling Orache, are relatively uncommon weeds moving north from the United States, but they have the potential to become more troublesome, especially if climate warming makes conditions in the prairies more suitable for their growth. ${ }^{6}$

The rarity of some saltbush species and the potential of others to become crop weeds in a changing climate make collection and identification of plants in this genus important. They are typically overlooked and seldom collected due to their lack of large, colourful flowers and their presence in habitats not frequently visited by naturalists (e.g. salt marshes and saline flats). Unusual specimens observed are therefore worth collecting and donating to 


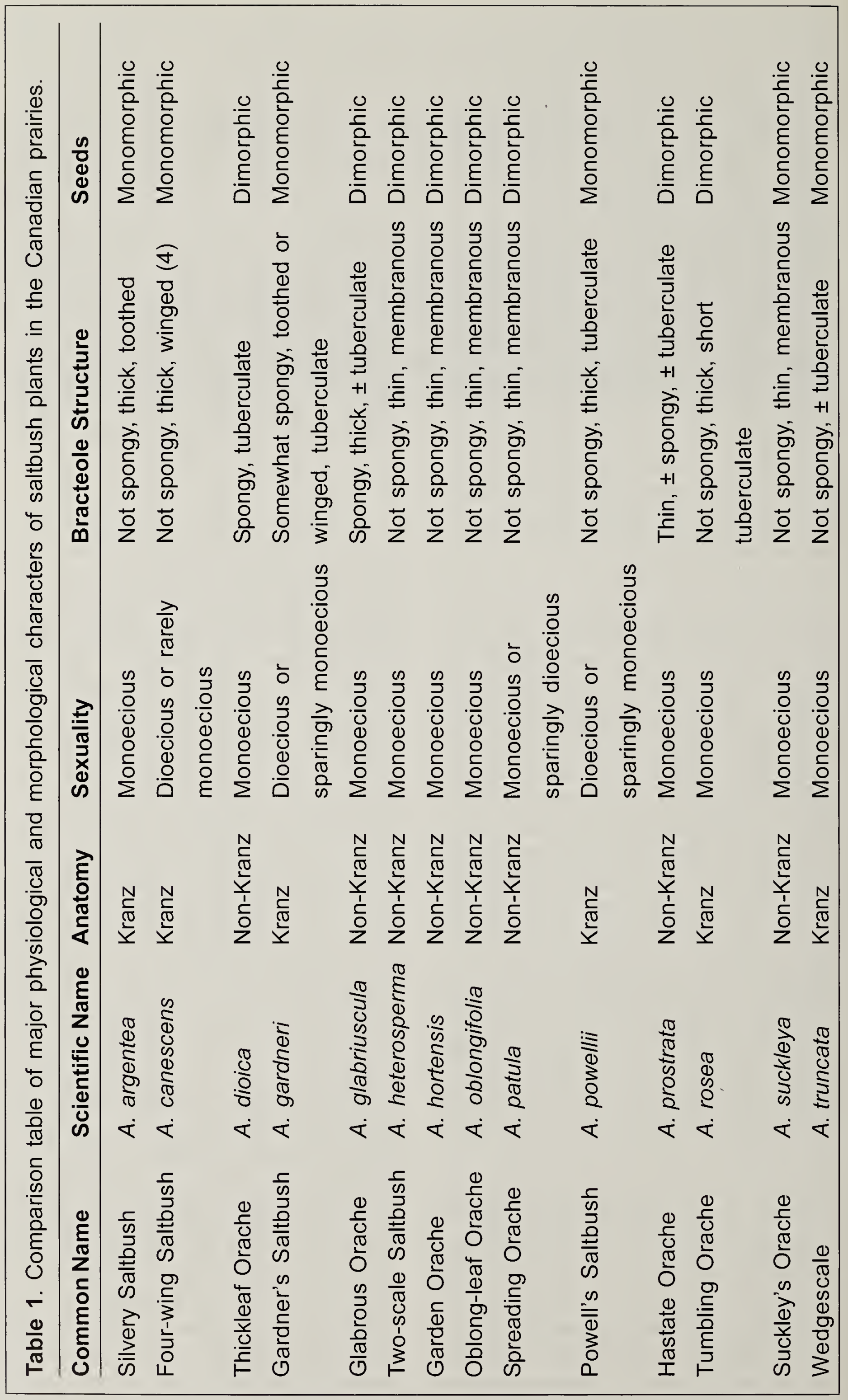


herbaria to better determine the distribution and frequency of these species. In general the best time to collect saltbush specimens is from August to October; mature specimens with well-developed bracteoles are the easiest to identify and immature specimens may be unidentifiable even by an expert.

\section{Economic Impact of Saltbushes}

Saltbushes are in the goosefoot family, which contains many of the species that we consider to be weeds including Russian Pigweed (Axyris amaranthoides L.), Russian-thistle (Salsola tragus L.), Lamb's-quarters (Chenopodium album L.) and Summer Cypress (Kochia scoparia (L.) Schrad.). ${ }^{16}$ However, it also contains several highly nutritious species such as Beet and Swiss Chard (Beta vulgaris L.), Quinoa (Chenopodium quinoa Willd.) and Spinach (Spinacia oleracea L.). ${ }^{18}$

The saltbush genus contains several species that have been eaten as "wild spinach." Garden Orache was a popular potherb in southeastern Europe and western Asia. ${ }^{18}$ In the past, this species was used in Italy to colour pasta red. Garden Orache seeds can still be purchased from specialty garden seed companies. As salinization of agricultural soils occurs, it may once again become a popular crop plant due to its natural salt tolerance. Other potherbs in this genus include Four-wing Saltbush, Hastate Orache, and Sea Purslane ( $A$. halimus L. $){ }^{18}$ Meat from sheep that have grazed on saltbush plants is noted to be particularly high in vitamin E. ${ }^{14}$

Since saltbush plants are windpollinated, they may cause rhinitus or hay fever in sensitized people. ${ }^{4}$ Saltbush plants typically flower in summer and fall and can produce copious quantities of pollen.

\section{Saltbush Characters}

The saltbush genus has a number of unusual characters that are useful in differentiating the species from each other. These characters are summarized in Table 1. Some saltbush species possess a special kind of plant anatomy called "Kranz" anatomy; the leaf veins are dark green and highly curled, unlike regular net, or reticulate-, veined species. ${ }^{4}$ To observe Kranz venation the underside of a leaf must be carefully scraped with a sharp blade to remove the surface scales and hairs and examined with a hand lens or microscope. Kranz anatomy enables these plants to use a photosynthetic pathway called $\mathrm{C} 4$ that is more efficient than the regular C3 pathway. 3,10 Kranz anatomy occurs in six species of saltbush found in the Canadian prairies along with a number of plants in other families, most commonly the warm season grasses. ${ }^{4}$ Blue Grama (Bouteloua gracilis (Willd. ex Kunth) Lag. ex Griffiths) and cord grasses (Spartina spp.) are examples of common C4 grasses.

Saltbushes have separate male (staminate) and female (pistillate) flowers, the former producing pollen in stamens and the latter producing seeds in pistils. The staminate flowers have a small calyx of 3-5 sepals while the pistillate flowers generally lack a calyx (Garden and Suckley's Orache are the exceptions). ${ }^{4}$ Some saltbush species produce both staminate and pistillate flowers on the same plant; these plants are called monoecious. Other saltbush species are dioecious with separate staminate and pistillate flowers on different plants. Some species produce plants with most flowers staminate or pistillate but with a few flowers of the opposite sex. 


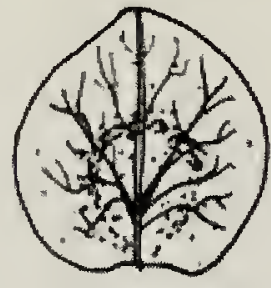

A. horfensis

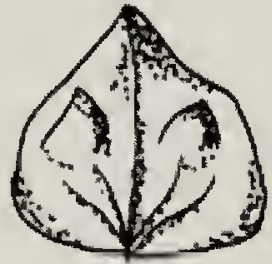

A. dioica

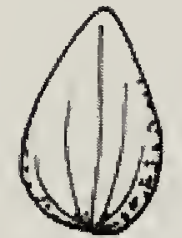

A. sucklevi

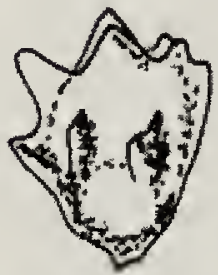

A. gardneri

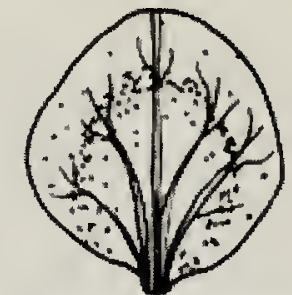

A. heterosperma

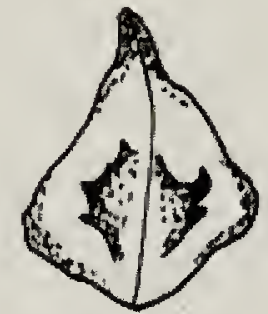

A. glabriscula

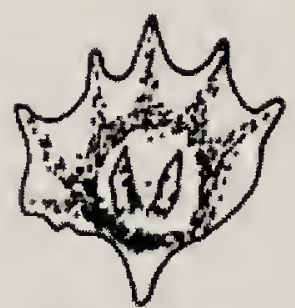

A. argentea

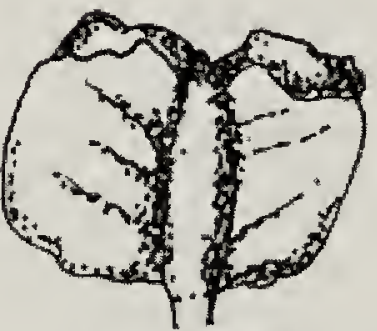

A. canescens

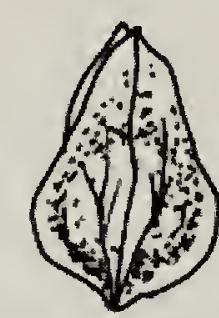

A. oblongifolia

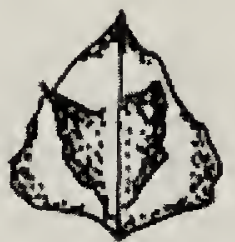

A. prostrata

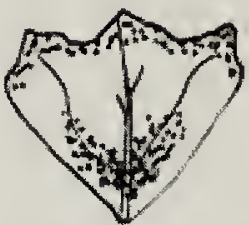

A. truncata

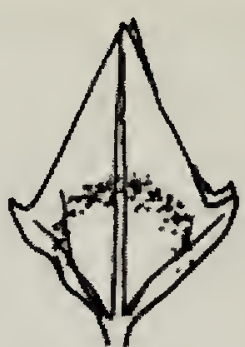

A. patula

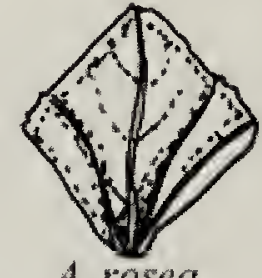

A. rosea

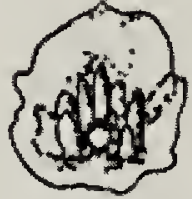

A. powellii

$D B R$

Figure 2. Saltbush fruiting bracteoles. Not drawn to scale.

D.B. Robson

The bracteoles, a pair of leaf-like bracts enclosing the flower, are the most important diagnostic characters of the saltbushes (Figure 2). ${ }^{4}$ Staminate flowers do not have bracteoles but pistillate flowers do, with the exception of some Garden Orache flowers. Bracteoles vary considerably in their shape, size, venation and texture. Bracteoles can be thin and membranous or thick, inflated and "spongy" in appearance. Many bracteoles are covered with protrusions called tubercules while others are smooth. Within a species there can also be variability in the appearance of the bracteoles: some are smooth while some have tubercules. For this reason, it is useful to look closely at several bracteoles on each plant to ensure that you observe the variety of textures that can occur.

Another unusual character of some saltbushes is the presence of two kinds of flowers and seeds. ${ }^{4}$ These plants are called dimorphic, meaning they have two forms. In dimorphic plants, some flowers have large, brown, vertical seeds while others produce small, black, horizontal seeds. The seeds also differ physiologically. The larger seeds are more salt-tolerant than the small seeds, however, the smaller seeds can remain dormant for longer periods of time, germinating when soil salinity is 


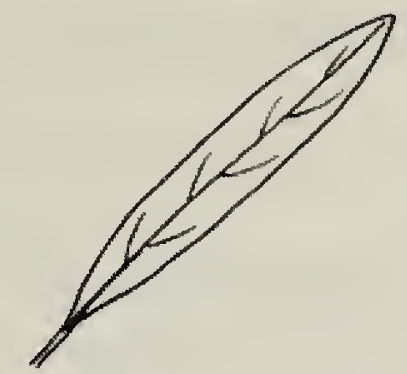

(a) linen

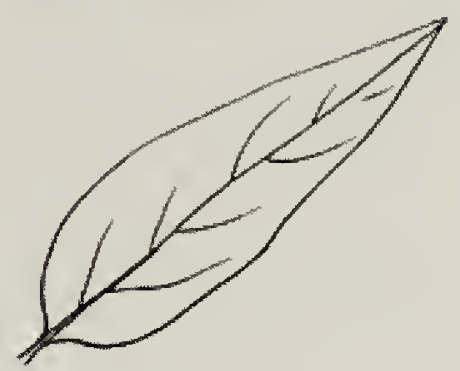

(c) lanceolate

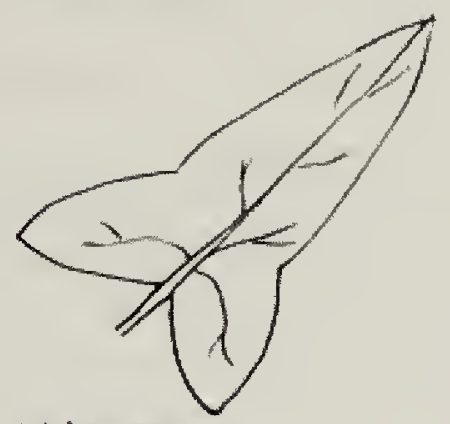

(e) hastate

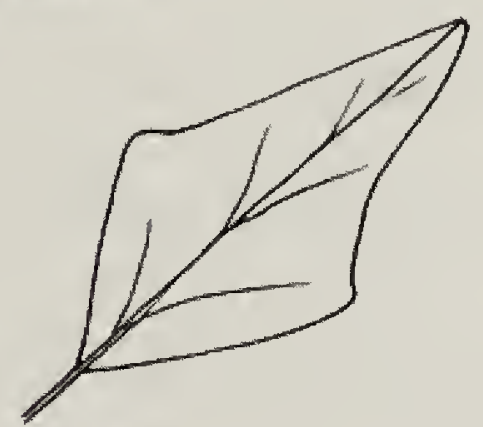

(g) rhombic

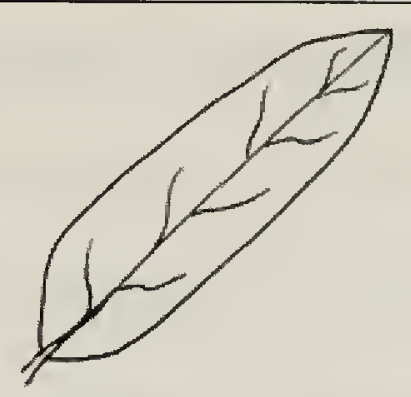

(b) oblong

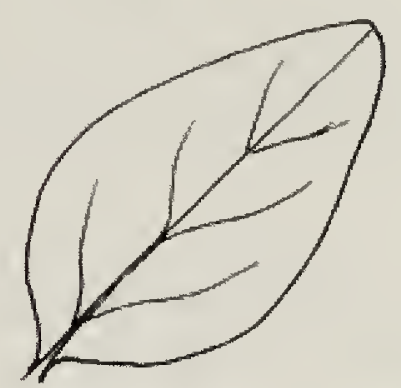

(d) ovate

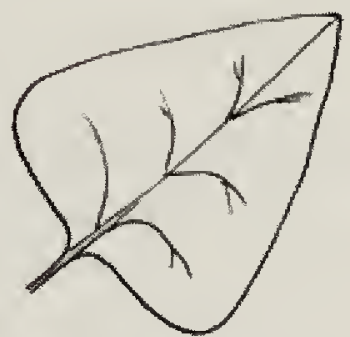

(f) triangular

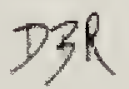

Figure 3. Leaf shapes common to saltbush species: (a) linear (b) oblong (c) lanceolate (d) ovate (e) hastate (f) triangular (g) rhombic.

D.B. Robson

not as high, such as in the spring. 5,20 Eight species of saltbushes in the Canadian prairie have dimorphic seeds and six have monomorphic (i.e. one kind) seeds. ${ }^{4}$

\section{Description of Atriplex 4, 9, 11, 13, 17, 19}

This genus contains a few perennial shrubs but mainly annual herbs, which are glabrous (i.e. smooth, lacking hairs or glands) or scurfy (i.e. covered with bladder-like hairs). The stems are erect to prostrate, typically branched and unarmed. The leaves are alternate, opposite or subopposite on the stem, with the upper leaves often smaller and of a different shape than the lower ones, stalked or rarely sessile, blades are linear, oblong, lanceolate, ovate, hastate, triangular or rhombic in shape (Figure 3 ), with blade margins that are entire, toothed, wavy or lobed near the base, Kranz or regular reticulate venation, green, silvery or white in colour and a sparsely to densely scurfy texture. The plants can be monoecious or dioecious. The inflorescences consist of both axillary and terminal 
1a. Perennial shrub or subshrub; leaves linear to oblong, not lobed 2

1b. Annual herbs; leaves typically broader, often hastate and lobed 3

2a. Shrubs to $60 \mathrm{~cm}$ tall; bracteoles with four prominent wings; rare

A. canescens

2b. Subshrubs to $40 \mathrm{~cm}$ tall; bracteoles with tubercules or short wings; common A. gardneri

3a. Leaves usually green on both surfaces, glabrous or sparingly powdery or finely scurfy at maturity

3b. Leaves white to grey, densely and finely scurfy at maturity, especially on the underside

4a. Bracteoles herbaceous or membranous with no spongy inner tissue ..... 5

4b. Bracteoles thickened, especially at the base, with spongy inner tissue ....8

5a. Bracteoles orbicular, always entire

5b. Bracteoles ovate, triangular or rhombic, may be toothed 7

6a. Bracteoles large (to $15 \mathrm{~mm}$ long), subcordate or broadly rounded at base, veins merging above the base (see Figure 2)

A. hortensis

6b. Bracteoles small (to $6 \mathrm{~mm}$ long), slightly pointed at the base, veins merging only at the base (see Figure 2)

A. heterosperma

7a. Bracteoles rhombic; terminal inflorescence of densely spaced glomerules; upper leaves green

A. patula

7b. Bracteoles ovate or triangular-ovate; terminal inflorescence of loosely spaced glomerules; upper leaves whitish below

A. oblongifolia

8a. Lower leaves linear or ovate-lanceolate

A. dioica

8b. Lower leaves triangular

9a. Inflorescence with leafy bracts to the tip; bracteoles thick and spongy; seeds mostly more than $2.5 \mathrm{~mm}$, only slightly dimorphic (of two kinds) ....

A. glabriuscula

9b. Inflorescence with leafy bracts only at base; bracteoles thin to slightly spongy; seeds mostly less than $2.5 \mathrm{~mm}$, distinctly dimorphic

A. prostrata 
10b.Lower leaves entire

11a.Sepals of staminate flowers pink, fused into a cup-shape and fleshy-lobed on back; pistillate bracteole ovate, entire A. suckleyi

11b. Sepals of staminate flowers green, not cup-shaped, lobes ovate, rounded on back; pistillate bracteole lanceolate, lobed, wavy or toothed 12

12a. Pistillate bracteoles obovate, $4-8 \mathrm{~mm}$ long A. argentea

12b. Pistillate bracteoles cuneate, spatulate or oblong, less than $4 \mathrm{~mm}$ long 13

13a. Pistillate bracteoles 2-3 mm long, cuneate and with three teeth at summit, smooth or with 1 or 2 small tubercles; leaves sessile or subsessile, not conspicuously nerved

A. truncata

13b. Pistillate bracteoles 3-4 mm long, spatulate to oblong, with short tubercules; lower leaves stalked, conspicuously 3-nerved A. powellii

spikes or spike-like panicles that may have leafy bracts at the base or scattered along the entire length. The flowers are imperfect and often occur in clusters called glomerules (i.e. dense, often rounded clusters of flowers). The staminate flowers are small and greenish, with no bracts or petals, but with a calyx of 3-5 partly fused sepals and 3-5 stamens. The pistillate flowers have 2 stigmas and a superior ovary, usually lack sepals and petals, and are subtended instead by two bracteoles that are distinct or fused at the base, membranous or with a layer of spongy tissue, round, lanceolate, ovate, triangular or rhombic in shape, margins entire, toothed or winged, surface smooth or possessing tubercules. The fruits are flattened, mainly vertical utricles (i.e. one-seeded fruits with thin, bladdery, inflated pericarps that are readily separable from the seed), or in many species dimorphic with large, brown and smaller, black seeds. The pericarp of the fruit usually comes off readily as the fruit is removed from the bracteoles and is rarely observed.
The imperfect flowers and the presence of bracteole pairs differentiate saltbushes from their close relatives the goosefoots (Chenopodium). Some saltbush species also resemble the docks (Rumex) but this genus has three bracteoles not two as in the saltbushes.

Descriptions of Saltbush Species 4,9 , $11,13,17,19$

The plants are arranged alphabetically by their scientific names. After each name there is a list of the synonyms for that species. (A synonym is a name that was formerly used for the plant.) The flowering period is noted in the descriptions; it can vary considerably depending on the geographic location and weather conditions. ${ }^{4}$

\section{Atriplex argentea Nutt. var. argentea - Silvery Saltbush or Silverscale}

A bushy annual growing $15-80 \mathrm{~cm}$ high, but usually smaller than $40 \mathrm{~cm}$. Stem angled, stout and whitish scurfy when young. Leaves greyish green, scurfy, with Kranz venation, to $3 \mathrm{~cm}$ long 
and 2.5-3 cm wide, lower leaves usually opposite and stalked, the upper alternate and sessile or nearly so; blades ovate, deltoid or lanceolate, apex acute to obtuse, base hastate to cuneate, margins entire or wavy. Monoecious with staminate flowers usually in terminal interrupted spikes, and pistillate flowers in axillary clusters. Staminate flowers with 4-5 sepals. Bracteoles of pistillate flowers obovate, thick but not spongy, united to the middle, firmly enclosing the fruit, the margins green and more or less toothed, surface smooth or with tubercules and 4-5 (8) $\mathrm{mm}$ long. Seeds rounded with a protruding tip, brown and to $1.7 \mathrm{~mm}$ long. June-August. Native and uncommon in saline flats and similar sites in southern Alberta and Saskatchewan, rare in Manitoba.

\section{Atriplex canescens (Pursh) Nutt.} var. canescens - Four-wing Saltbush

A perennial shrub, erect or semi-erect and branching from a woody base with upper stems herbaceous, $15-60 \mathrm{~cm}$ high. Leaves deciduous, whitish grey to pale green, densely scurfy, with Kranz venation, $10-40 \mathrm{~mm}$ long and $3-8 \mathrm{~mm}$ wide, alternate or nearly sessile; blade linear to oblong, oblanceolate or obovate, apex retuse to obtuse, base acute, margin entire. Dioecious or rarely monoecious; flowers in leafy panicles. Staminate flowers yellow to light brown, in clusters, 2-3 $\mathrm{mm}$ wide. Bracteoles of pistillate flowers in clusters with 1-8 $\mathrm{mm}$ long petioles, surface smooth or reticulate, ellipsoid with four prominent wings extending the bract length, apex toothed, margin dentate to entire, 8-25 mm long. Seeds teardrop-shaped, brown and 1.5-2.5 $\mathrm{mm}$ long. July-August. Native and rare in saline flats of southern Alberta.

\section{Atriplex dioica Raf. - Thickleaf Orache or Saline Saltbush [ $A$. subspicata (Nutt.) Rydb., A. patula L.}

var. subspicata (Nutt.) S. Wats., A. p. ssp. p. (Nutt.) Fosb., A. p. ssp. hastata auct. p.p. non (L.) Gray. Please note that $A$. dioica (Nutt.) Macbr. is the synonym for $A$. suckleyi (Torr.) Rydb.]

An erect herbaceous annual, 3-15 $\mathrm{dm}$ tall. Stems angular and reddish. Leaves green to greyish green, reddish at maturity, scurfy, $2-12 \mathrm{~cm}$ long and 0.5 $6 \mathrm{~cm}$ wide, opposite or subopposite, petiolate or the upper sessile, blade narrowly to broadly lanceolate to lanceolate-linear, apex acute to rounded, often with a pair of narrow, straight or forward-curving lobes towards the base, margin irregularly toothed to entire. Monoecious; flowers in glomerules, arranged in continuous or interrupted terminal and axillary spikes, and 2-9 cm long. Bracteoles of pistillate flowers green, blackening with age, with an inner spongy tissue, triangular to ovate-triangular, margins united at base and entire or shorttoothed, dorsal surface smooth or with one or more tubercules, 3-10 $\mathrm{mm}$ long. Seeds are round and of two kinds: some brown, dull and 1.5-3 mm long, and others shiny, black and 1-2 $\mathrm{mm}$ long. July-August. Native and uncommon in saline and alkaline prairie, parkland and southern boreal forest of the Prairie Provinces.

\section{Atriplex gardneri (Moq.-Tan.) D. Dietrich - Gardner's Saltbush, Nuttall's Saltbush, Moundscale, Salt- sage}

[A. nuttallii auct. p.p. non S. Wats., A. $n$. ssp. gardneri (Moq.) Hall \& Clements, A. n. ssp. buxifolia (Rydb.) Hall \& Clements, $A$. falcata auct. non (M.E. Jones) Standl., A. buxifolia Rydb., A. gordonii Hook., A. oblanceolata Rydb., A. aptera A. Nels., A. canescens SK auct. non (Pursh) Nutt., A. c. var. aptera (A. Nels.) Welsh \& C.L. Hitchc., A. c. ssp. a. (A. Nels.) Hall \& Clem.]

A perennial subshrub to $40 \mathrm{~cm}$ high, branching from a woody base. Stems 
decumbent to ascending, rarely erect, whitish grey to pale green in colour, upper stems herbaceous. Leaves whitish grey to pale green, densely scurfy, with Kranz venation, 12-55 mm long and 5-12 mm wide, persistent or subpersistent, alternate or opposite to subopposite, sessile to petiolate; blade linear to oblanceolate, obovate, spatulate or orbiculate, apex retuse to obtuse or rounded, base cuneate, margin entire. Dioecious or sparingly monoecious; staminate flowers in dense spikes or panicles $3-18 \mathrm{~cm}$ long, pistillate flowers in spikes or panicles 8-25 cm long. Staminate flowers brown or yellow, in clusters $2-4 \mathrm{~mm}$ wide. Fruiting bracteoles of pistillate flowers sessile or on a 2-5 mm long stalk, with somewhat spongy inner tissue, smooth, with tubercules or four short wings, oval in shape, apex toothed, margins united at or above the middle, to $1.5 \mathrm{~mm}$ long. Seeds short, teardropshaped, tan or brown and 1.5-2.5 mm wide. July-August. Two varieties are found in the prairies and these can be distinguished using the following key:

1a Fruiting bracteoles with 4 short wings or rows of tubercules; staminate flowers yellow .... var. aptera (A. Nels.) Welsh \& Crompton

1b. Fruiting bracteoles lacking lateral wings; staminate flowers yellow or dark brown ..var. gardneri

The variety gardneri is native and common in southern prairies, on finetextured saline soils. The variety aptera (called Nelson's Saltbush) occurs on dry, mixed-grass prairie and barren clay-flats only in southern Alberta and Saskatchewan.

\section{Atriplex glabriuscula Edmondston var. glabriuscula - Glabrous Orache}

An annual herb, 1-10 dm tall, that is prostrate or less commonly erect and branched. Stems green-striped, weakly ridged and sparsely scurfy to glabrous. Leaves somewhat succulent, green, glabrous to sparsely powdery underneath and on veins, upper leaves smaller than lower ones, $0.5-10 \mathrm{~cm}$ long and $0.3-8 \mathrm{~cm}$ wide, alternate, petiolate; blade triangular or lancehastate, apex acute, base cuneate, usually with a pair of upwards-curving lobes, entire or irregularly toothed. Monoecious; inflorescence of loose glomerules in leaf axils or short spikes with leafy bracts to the tip. Bracteoles of pistillate flowers green becoming black, reddish or brown, thick with spongy inner tissue, veins obscure, surface smooth or tuberculate, ovatetriangular to rhombic-triangular, apex abruptly acuminate to a thin tip, margin united almost to middle with few irregular teeth, 5-13 mm long. Seeds round to oval, of two kinds: some brown, convex and 2.5-4 mm wide, and others rarely black and 1.5-2.9 mm wide. JulyAugust. Native and rare in saline or brackish marshes and saline coastal strands of northern Manitoba along Hudson Bay and possibly northeastern Alberta.

\section{Atriplex heterosperma Bunge - Two-scale Saltbush}

[A. micrantha auct. non Ledeb.]

An erect, herbaceous annual, branching from the base and 10-15 dm tall. Leaves green, scurfy below and becoming glabrate with age, to $6.5 \mathrm{~cm}$ long, alternate, except uppermost leaves which are opposite, with 2-3 cm long petioles; blade triangular, as long as wide, base hastate to cuneate, often with auricles. Monoecious with flowers in loosely branched terminal or axillary panicles. Staminate flowers with 5 sepals. Bracteoles membranous, not fused, slightly pointed at the base, with veins all converging at the base, smooth, orbicular-ovate, of two sizes, the larger 5-6 mm long, and the smaller 
$2 \mathrm{~mm}$ long. Seeds rounded, of two kinds: some yellow-brown, flat, dull and 2-3 mm diameter, and others black, shiny, biconvex and to $1.5 \mathrm{~mm}$. AugustSeptember. Introduced and uncommon on roadsides and waste ground in Alberta and possibly Saskatchewan.

\section{Atriplex hortensis L. - Garden} Orache or French Spinach (See photograph on inside back cover, top)

A fairly tall, erect to half decumbent, highly branched, annual plant, 60-120 $\mathrm{cm}$ high. Leaves green, sparsely scurfy becoming glabrous with age, 15-180 $\mathrm{mm}$ long and 8-135 mm wide, opposite or alternate, with $0.3-4 \mathrm{~cm}$ petioles, blade cordate, triangular to triangular ovate with a hastate base, apex attenuate to acuminate or rounded, entire or irregularly toothed. Monoecious; flowers in spikes of leafless panicles. Staminate flowers with 5 sepals. Pistillate flowers of two kinds: some lacking bracts but with a 5-parted calyx, and others with bracteoles instead of a calyx. Bracteoles membranous, entire, surface smooth, united only at base, with veins merging above the base, orbicular-ovate, subcordate or broadly rounded at base, 5-18 mm long. Seeds rounded, of two kinds: those enclosed in bracteoles yellow-brown, flat, dull and $2-3 \mathrm{~mm}$ diameter, and those in the calyx, black, shiny, biconvex and to 1.5 $\mathrm{mm}$. July-August. Introduced and common. A garden escape that has become very common around towns and cities in all three Prairie Provinces.

\section{Atriplex oblongifolia Waldst. \& Kit. - Oblong-leaf Orache}

An erect annual to $12 \mathrm{dm}$ tall that branches from the base. Leaves green above, whitish and scurfy underneath becoming glabrous with age, up to 7 $\mathrm{cm}$ long and $2.5 \mathrm{~cm}$ wide, alternate except near the base, with $0.5-3 \mathrm{~cm}$ long petioles; blade oblong-lanceolate, widest near the cuneate or hastate base, apex acute, margin entire or irregularly dentate. Monoecious; flowers in Joosely spaced, terminal or axillary inflorescences that elongate at maturity. Staminate flowers with 5 sepals. Bracteoles of pistillate flowers thin, smooth and lacking appendages, ovoid-rhombic or triangular-ovate, acute to rounded at apex, margins entire, of two sizes, the larger to 5-6 $\mathrm{mm}$ long, and the smaller ones $2 \mathrm{~mm}$ long. Seeds rounded, of two kinds: some yellow-brown, flat, dull and 2-4 $\mathrm{mm}$ diameter, and others black, shiny and to $1.5 \mathrm{~mm}$ in diameter. AugustSeptember. Introduced but rare in Alberta and possibly Saskatchewan along roadsides and waste ground.

\section{Atriplex patula L. - Spreading Orache, Spear Saltbush, Fat-hen Saltbush or Spear-scale}

[A. hastata ssp. patula (L.) S. Pons., A. h. var. patula (L.) Farwell, A. patula var. bracteata auct. non Westerl., $A$. $p$. var. japonica Level., Teutiopsis patula (L.) Selak]

An annual herb that is erect or less commonly prostrate, simple or branched and $15-150 \mathrm{~cm}$ tall. Stems opposite to subopposite, straight with green stripes. Leaves green, glabrous to sparsely powdery underneath, 2.5$12 \mathrm{~cm}$ long and $3-40 \mathrm{~mm}$ wide, alternate above, with $0.5-2 \mathrm{~cm}$ petioles, upper leaf blades lanceolate to oblonglinear, lower leaf blades rhombiclanceolate or hastate-ovate, apex acute, base cuneate or hastate, margin entire or irregularly toothed. Monoecious or rarely dioecious; flowers in dense glomerules, arranged in interrupted axillary and terminal spikes that have leafy bracts only at the base. Staminate flowers mostly with 5 sepals. Bracteoles thin, green becoming black, rhombic to rhombic-triangular or ovaterhombic, apex acute, base mostly hastate, margin united almost to 
middle, entire or sparingly toothed, tuberculate, 2-7 $\mathrm{mm}$ long. Seeds round, of two kinds: some brown and 2.5-3 $\mathrm{mm}$ wide, and others black and 1-2 mm wide. Often mistaken for Lamb's-quarters. July-September. Introduced and uncommon on disturbed and saline areas in prairies and parklands.

10. Atriplex powellii S. Wats. var. powellii-Powell's Saltbush

Annual herb, branched from the base with the lower branches curving upwards and longer than the upper ones, and $10-50 \mathrm{~cm}$ high. Leaves grey and scurfy, conspicuously 3-nerved, with Kranz venation, $5-25 \mathrm{~mm}$ long and about as wide, alternate, lower leaves petiolate, upper leaves sessile; blade deltoid-ovate to orbicular-ovate or cordate-ovate to elliptic, base obtuse to cuneate, margin entire or undulate. Dioecious or sparingly monoecious; flowers in glomerules in terminal and axillary spikes. Staminate flowers with 4-5 sepals. Bracteoles of pistillate flowers sessile, united to the apex and firmly enclosing the fruit, thick but not spongy, surface smooth or with few to many tubercules, spatulate to oblong, the margins more or less toothed, 3-4 $\mathrm{mm}$ long and nearly as wide. Seeds rounded, light brown to yellowish brown and $1.5 \mathrm{~mm}$ long. July-August. Native and rare on sub-saline clay flats, badlands and alkali flats in Alberta and Saskatchewan.

11. Atriplex prostrata Bouch. ex DC. Hastate Saltbush or Halbert-leaved Saltbush

[A. hastata auct. non L., A. latifolia Wahl., A. patula L. var. triangularis (Willd.) Thorne \& Welsh, A. patula var. hastata auct. non (L.) Gray, A. prostrata var. triangularis (Willd.) Rausch, $A$. $t$. Willd.]

An annual herb that is erect, procumbent or decumbent and branched from the base, 1-10 dm tall.
Branches opposite or subopposite each other with green stripes. Leaves somewhat succulent, green, glabrous to sparsely powdery underneath and on veins, upper leaves smaller than lower ones, 20-100 mm long and almost as wide, opposite or subopposite, with 1-3 cm petioles, blade triangular-hastate, usually with a pair of spreading basal lobes, apex acute to obtuse, base truncate or subcordate, margin entire, serrate, dentate or irregularly toothed. Monoecious; inflorescences of terminal and axillary spikes that are 2$9 \mathrm{~cm}$ long and leafy only at the base. Bracteoles green becoming black or brown at maturity, thin with some spongy inner tissue, veined or veins obscure, smooth or with 2 tubercles, ovate triangular to triangular-hastate, apex acute, margin united at base, 3-5 $\mathrm{mm}$ long. Seeds round, of two kinds: some brown, flat and 1-2.5 mm wide, and others black and $1-1.5 \mathrm{~mm}$ wide. July-August. Introduced and common on slough edges, alkaline and saline flats in prairie, parkland and southern boreal forest.

\section{Atriplex rosea L. - Tumbling Orache, Red Orache or Red-scale}

An erect annual herb, simple or branched, whitish scurfy or glabrate and 1-10 $(-20) \mathrm{dm}$ tall. Leaves grey or whitish, rarely green, prominently 3veined with Kranz venation, $12-80 \mathrm{~mm}$ long and 6-50 $\mathrm{mm}$ wide, alternate, upper sessile, lower short petiolate; blade lanceolate to ovate, apex acute to obtuse, margin sinuate-dentate and often lobed. Monoecious; flowers in glomerules arranged in slender, simple or paniculate spikes that lack or have a few leafy bracts. Staminate flowers with 4-5 sepals. Bracteoles of pistillate flowers sessile, united to near the middle, surface smooth or with short tubercules, strongly 3 veined, rhombic or ovate, margin dentate, $4-8 \mathrm{~mm}$ long. 
Seeds dull brown and 1.5-2 $\mathrm{mm}$ across. July-August. Introduced and uncommon on roadsides and waste ground in southern prairies.

\section{Atriplex suckleyi (Torr.) Rydb. - Suckley's Orache or Rillscale}

[Atriplex dioica (Nutt.) Macbr. Endolepis dioica (Nutt.) Standl. E. suckleyi Torr.]

A low, erect, annual herb, spreading and branching from the base, almost glabrous, to $30 \mathrm{~cm}$ high. Stems often tinged with red, sparsely mealy or glabrous. Leaves thick, succulent, with 1 nerve, pale green, sparsely scurfy when young, 7-35 mm long and 4-10 $\mathrm{mm}$ wide, alternate, sessile; blade lanceolate to elliptic or less commonly ovate, apex acute or acuminate, margins entire. Monoecious with male flowers in small glomerules mostly arranged in terminal spikes, female flowers solitary to few, in leaf axils. Staminate flowers with a cup-shaped, pinkish calyx that has fleshy lobes; stamens 5 . Pistillate flowers with 3-4 sepals that are distinct, obtuse, entire or lobed and with hyaline margins. Bracteoles of pistillate flowers membranous, sessile, united to apex, smooth, scurfy, ovate, $1 \mathrm{~mm}$ long and $1.5 \mathrm{~mm}$ wide. Seeds ovate, brown, 1.5 $\mathrm{mm}$ long and $1.2 \mathrm{~mm}$ wide. JuneAugust. Native and uncommon, but plentiful locally. Found on saline flats, eroded clay slopes, and badlands throughout southern Prairies.

\section{Atriplex truncata (Torr. ex S. Wats.) A. Gray - Wedgescale or Wedge- leaved Saltbush}

An erect, herbaceous annual, often freely branched, 2-8 (10) dm tall. Stems obtusely angled, scurfy becoming glabrate. Leaves grey-scurfy or the upper surface glabrate, with Kranz venation, not conspicuously nerved, 4$30 \mathrm{~mm}$ long and $3-30 \mathrm{~mm}$ wide, alternate or uppermost leaves opposite, sessile or subsessile; blade broadly ovate to deltoid or oval, apex acute to obtuse, base cuneate to subcordate or somewhat hastate, margin entire or dentate and sometimes undulate. Monoecious with flowers in glomerules arranged mainly in axillary spikes. Staminate flowers with 3-5 sepals. Bracteoles of pistillate flowers cuneate, with 3 teeth at the apex or broadly rounded, surface smooth or with 1 or 2 small tubercules, 2-3 $\mathrm{mm}$ long and as wide. Seeds round, brown and about $1.5 \mathrm{~mm}$ across. JulyAugust. Native and rare on dry, alkaline flats, slopes and sloughs in Alberta and Saskatchewan.

\section{Acknowledgements}

Financial support for this research was received from The Manitoba Museum Foundation Inc. Specimen loans were graciously supplied by the herbaria at the University of Regina (USAS), University of Alberta (ALTA) and the Department of Agriculture (DAO). The herbarium at the University of Saskatchewan (SASK) was visited by the author.

1. ACTON, D.F., G.A. PADBURY, and C.T. STUSHNOFF. 1998. The ecoregions of Saskatchewan. Canadian Plains Research Centre, University of Regina, Saskatoon, SK.

2. ARGUS, G.W., and K.M. PRYER. 1990. Rare vascular plants in Canada. Canadian Museum of Nature, Ottawa, ON.

3. BARBOUR, M.G., J.H. BURK, and W.D. PITTS. 1987. Terrestrial Plant Ecology. Benjamin/ Cummings Publishing Co., Don Mills, ON.

4. BASSETT, I.J., C.W. CROMPTON, J. MCNEILL, and P.M. TASCHEREAU. 1983. The genus Atriplex (Chenopodiaceae) in Canada. Monograph No. 31. Agriculture Canada, Ottawa, ON.

5. CARTER, C.T., and I.A. UNGAR. 2003. Germination responses of dimorphic seeds of two halophyte species to environmentally controlled and natural conditions. Canadian Journal of Botany 81: $918-926$.

6. DUKES, J.S., and H.A. MOONEY. 1999. Does global change increase the success of biological invaders? Trends in Ecology \& Evolution 14:135139. 
7. HARMS, V.L. 2003. Checklist of the vascular plants of Saskatchewan and the provincially and nationally rare native plants in Saskatchewan. University Extension Press, Saskatoon, SK.

8. JOHNSON, K.L. 1987. Wildflowers of Churchill and the Hudson Bay region. Manitoba Museum of Man and Nature, Winnipeg, MB

9. KERSHAW, L., J. GOULD, D. JOHNSON, and J. LANCASTER. 2003. Rare Vascular Plants of Alberta. University of Alberta Press, Edmonton, $\mathrm{AB}$.

10. LARCHER, W. 1973. Physiological Plant Ecology. Springer-Verlag, New York.

11. LOOMAN, J., and K.F. BEST. 1979. Budd's Flora of the Canadian Prairie Provinces. Canadian Government Publishing Centre, Supply and Services Canada, Hull, QU.

12. MAHER, R.V., G.W. ARGUS, V.L. HARMS and J.H. HUDSON. 1979. The Rare Vascular Plants of Saskatchewan. National Museum of Canada, Ottawa, ON.

13. MOSS, E.H. 1983. Flora of Alberta $\left(2^{\text {nd }}\right.$ edition by J.G. Packer). University of Toronto Press, Toronto, ON.

14. PEARCE, K., and R. JACOB. 2004. Saltbush lifts sheep meat vitamin content. Farming Ahead 153: 63.
15. ROBSON, D.B. 1999. Reasons for prairie plant rarity. In J. Thorpe, T.A. Steeves, and M. Gollop, (eds.) Proceedings of the 5th Prairie Conservation and Endangered Species Conference. Provincial Museum of Alberta, Edmonton, $\mathrm{AB}$.

16. ROYER, F., and R. DICKENSON. 1999. Weeds of Canada and the Northern United States. University of Alberta Press and Lone Pine Publishing, Edmonton, AB.

17. SCOGGAN, H.J. 1956. Flora of Manitoba. National Museum of Canada, Ottawa, ON.

18. VAN WYK, B. 2005. Food plants of the World. Timber Press. Portland, OR.

19. WELSH, S.L., C.W. CROMPTON, and S.E. CLEMENTS. 2003. Chenopodiaceae. In: Flora of North America Editorial Committee, (eds.)Flora of North America, volume 4. Oxford University Press, New York, NY. pp. 258-404.

20. WERTIS, B.A., and I.A. UNGAR. 1986. Seed demography and seedling survival in a population of Atriplex triangularis Willd. American Midland Naturalist 116: 152-162.

21. WHITE, D.J., and K.L. JOHNSON. 1980. The Rare Vascular Plants of Manitoba. National Museum of Canada, Ottawa, ON.

\title{
DISPLACEMENT
}

\author{
A raven landing \\ on snow-laden branches \\ sends an instant shower \\ down upon house finches \\ huddled far below him
}

a second snow fall for them.

\author{
Victor C. Friesen
}

